\title{
SOVIET POLICY SCIENCES AND EARTH SYSTEM GOVERNMENTALITY*
}

\section{EGLE் RINDZEVIČİ̄TĖ}

Faculty of Arts and Social Sciences, Kingston University

E-mail: E.Rindzeviciute@kingston.ac.uk

This article introduces non-Western policy sciences into the burgeoning field of the intellectual history of Earth system governmentality, a field that studies the ideas, institutions and material systems that enable action at the global scale. It outlines the rise of debates on the idea of the governability of the global biosphere in late Soviet Russia (1970s-1980s), focusing particularly on the extension of Vladimir Vernadskii's famous theory of the biosphere and its governance (the stage of the noosphere) into computer modeling and systems analysis. As a result, a new notion of governance as guidance through milieu arose to conceptualize global governance of the biosphere. This conceptual innovation was part of Soviet scientists' attempt to liberalize the centrally commanded Soviet governmental system.

Recent work has established a new research agenda in the field of "Earth system governmentality," an interdisciplinary area of study that combines the perspectives of environmental history, international organization and studies of science and technology to investigate the social and political consequences of the emerging role of mankind as a geological force. ${ }^{1}$ However, the bulk of this work has focused on developments in the West, despite the fact that

* This work was supported by the European Research Council under an ERC Grant 283706 awarded to the A Political History of the Future: Knowledge Production and Future Governance 1945-2010 (Futurepol) project, PI Prof. Jenny Andersson, the Paris Institute of Political Studies (Sciences Po), France, 2012-15. I thank the four anonymous reviewers and the editors of Modern Intellectual History for their constructive and helpful comments and I am particularly grateful to Paul Warde, Jonathan Oldfield and Francis Dodsworth for their generous feedback at various stages of this work.

1 Michael Mahony and Martin Hulme, "Epistemic Geographies of Climate Change: Science, Space and Politics," Progress in Human Geography (2016), 1-30. For antecedents of the Anthropocene concept see Christophe Bonneuil and Jean-Baptiste Fressoz, The Shock of the Anthropocene: The Earth, History and Us (London, 2016); Libby Robin, Sverker Sorlin 
Earth system governance was by nature a global movement. This article seeks to augment our understanding of the emergence of Earth system governmentality by exploring the subject from the Soviet perspective. It argues that not only were developments in the Soviet Union vital to the emergence of the concept, but also the process of developing concepts of Earth system governance drove a fundamental revision of authoritarian dogmas of governability and concepts of man's relationship with nature. Through this process, the Soviet version of Earth system governmentality contributed to the development of a "liberal" model of negative governance, which emphasized the limits to intervention rather than policy and management targets to be achieved, an intellectual innovation that was rooted in the advancement of computer modeling technology and East-West intellectual transfer.

It is centrally important to include the Soviet case in the intellectual history of Earth system governance, not least because Paul Crutzen, the originator of the concept of the Anthropocene, attributed its intellectual origins to Russian theories of the biosphere and noosphere. ${ }^{2}$ The origin of the concept of the biosphere, designating the Earth's layer that is characterized by living matter, dates to the second half of the nineteenth century. Conversely, its sibling concept, the noosphere, was developed by the Russian geologist and natural scientist Vladimir Vernadskii (1863-1945) and French philosophers Pierre Teilhard de Chardin and Édouard Le Roy, whom Vernadskii met in Paris in 1922-5. ${ }^{3}$ Vernadskii's book The Biosphere (published in Russia in 1926, first translated into English only in 1986) posited that living matter was shaped through the interaction of solar energy and bio-geophysical processes. While Teilhard de Chardin created the concept of the noosphere to describe the ultimate stage of human progress, where cosmos, God, reason and the material world would unite, Vernadskii saw the noosphere as a stage of the development of living matter, the biosphere, where humankind becomes a geological force and human reason ( razum in Russian) acquires power to drive the change. ${ }^{4}$ A noosphere is therefore a particular stage of biospheric development, where global coevolution becomes governable. ${ }^{5}$

and Paul Warde, eds., The Future of Nature: The Documents of Global Change (New Haven, 2013).

$2 \quad$ Paul Crutzen, "Geology of Mankind," Nature, 415/3 (2002), 23.

3 Will Steffen et al., "Planetary Boundaries: Guiding Human Development on a Changing Planet," Science 347 (2015), 736.

$4 \quad$ Jonathan Oldfield and Denis Shaw, eds., The Development of Russian Environmental Thought: Scientific and Geographical Perspectives on the Natural Environment (London, 2016).

5 Although Vernadskii's biosphere theory is familiar to environmental historians, the Russian version of noosphere theory is little known in the West. Jonathan Oldfield and Denis Shaw, "V. I. Vernadskii and the Development of Biogeochemical Understandings of 
Vernadskii's legacy significantly shaped Soviet thought on global governance during the Cold War as his geophysical philosophy was extended beyond the natural sciences into the new field of decision and policy sciences, characterized by operations research (OR), economic and management cybernetics and systems analysis. ${ }^{6}$ While there is a growing Anglo-American historiography on the Soviet version of Cold War policy sciences, including their environmental applications, this is the first account of the rapprochement between Soviet policy sciences and Western Earth system governance. ${ }^{7}$ The purpose is to add a global-governance dimension to the well-established work on environmental politics in the Soviet Union. ${ }^{8}$

The empirical focus is on the prominent Soviet Russian scientist Nikita Moiseev (1917-2000), who transformed Vernadskii's geophysical philosophy into an applied policy science, entrenched in the global concerns of the Cold War. For Moiseev, to govern the global biosphere required the invention of new policy sciences, which would enable humanity to step into the stage of the noosphere. It is difficult to overstate Moiseev's intellectual and political significance for the opening up of Soviet science to international cooperation. Moiseev was a patron of global computer modeling in the Soviet Union, and in the early 1980 s he cooperated with Crutzen on the famous nuclear winter study, a computer simulation of the environmental effects of nuclear war. While the legacy of the nuclear winter study can certainly be seen in Crutzen's formulation of the Anthropocene theory, Moiseev used the nuclear winter simulation to argue that the idea of governing the global biosphere was not a utopia, but a challenge for

the Biosphere, c.1880s-1968," British Journal for the History of Science 46/2 (2013), 287-310; Stanislav Shmelev, Ecological Economics: Sustainability in Practice (Berlin, 2012); Rafal Serafin, "Noosphere, Gaia and the Science of the Biosphere," Environmental Ethics 10/2 (1988), 121-37; Nikita Moiseev, "Reflection on Noosphere: Humanism in Our Time," in David Pitt and Paul Samson, eds., The Biosphere and Noosphere Reader: Global Environment, Society and Change (London and New York, 1999), 167-79.

6 See the volume comprising statements on Vernadskii's influence by scientists representing different disciplines: Andrei Lapo and Aleksandr Ianshin, eds., V. I. Vernadskii: Pro et Contra (St. Petersburg, 200o).

$7 \quad$ Also see Egle Rindzevičiūte, The Power of Systems: How Policy Sciences Opened Up the Cold War World (Ithaca, 2016); Giulia Rispoli, "Between 'Biosphere' and 'Gaia': Earth as a Living Organism in Soviet Geo-ecology," Cosmos and History: The Journal of Natural and Social Philosophy 10/2 (2014), 78-91; Jonathan Oldfield, "Russia, Systemic Transformation and the Concept of Sustainable Development," Environmental Politics 10/3 (2001), 94-110.

8 For important studies see Douglas R. Weiner, A Little Corner of Freedom: Russian Nature Protection from Stalin to Gorbachev (Berkeley, 1999); Paul Josephson, Nicolai Dronin, Ruben Mnatsakanian, Aleh Cherp, Dmitry Efremenko, and Vladislav Larin, An Environmental History of Russia (Cambridge, 2013); Andy Bruno, The Nature of Soviet Power: An Arctic Environmental History (Cambridge, 2016). 
policy science. Furthermore, Moiseev was also a high-level policy adviser: he informally advised Mikhail Gorbachev when the latter was the chairman of the Stavropol region and the general secretary of the Communist Party of the Soviet Union (CPSU). ${ }^{9}$ The extent of Moiseev's contribution to Gorbachev's domestic and foreign policy will not be clear until archival materials become available in the future. However, Moiseev's role in the promotion of new technologies alongside new normative epistemologies is fairly evident: in addition to global climate modeling, Moiseev initiated the development of a computerized decision-making model for agricultural development in the Stavropol region, a project which was implemented in cooperation with the International Institute of Applied Systems Analysis (IIASA) in Laxenburg, Austria. ${ }^{10}$ Moiseev was also central to the introduction of "global problems" as a priority area in the CPSU's long-term plan in 1986, i.e. global issues such as carbon dioxide emissions, world population growth and world energy resources, which cannot be resolved by a single state. Furthermore, Moiseev had a wide societal impact as a prolific popularizer of science: his books were published in runs of thousands of copies and were widely read in society and by managerial elites in the 1980 s. Since his death in the year 2000, the intellectual legacy of Moiseev has been fostered by institutes of the Russian Academy of Sciences and leading university departments. ${ }^{11}$

9 This is based on Moiseev's contemporaries' memoirs; a study of archival materials is necessary in order to establish the concrete forms of Gorbachev's and Moiseev's relation. Aleksandr A. Petrov, Nikita Nikolaevich Moiseev: Sud' ba strany v sud'be uchenogo (Nikita Nikolaevich Moiseev: The Destiny of the Country in the Destiny of the Scientist) (Moscow, 2011), 106-7.

10 Ibid., 107-9. This agricultural decision-making model was developed by F. Ereshko, V. Y. Lebedev and K. Parikh in 1983. See I. V. Iakimets, "Background and Requirements for the SOVAM: Soviet Agricultural Model," IIASA working paper, WP-84-097, IIASA, Austria, 1984.

$11 \quad$ Moiseev's biographies and volumes engaging with his work were published shortly after his death in 200o. See Ivan Larin, On uchil berech zemliu (He Taught to Protect the Earth) (Moscow, 2002); Voprosy filosofi, Myslitel' planetarnogo mashtaba: materialy "kruglogo stola" po kn. N. N. Moiseeva "Byt' ili ne byt' chelovechestvu?" (The Issues of Philosophy, A Thinker of a Planetary Scale: Proceedings of a Round Table on N. N. Moiseev's Book "Humanity: To Be or Not to Be?") (Moscow, 2000). Prominent politicians such as former Prime Minister Evgenii Primakov endorsed Moiseev's contributions. Evgenii Primakov, "Nikita Moiseev: vydaiushchii sia uchenyi i grazhdanin," Alma Mater 6 (2007), 43. Many contemporary Russian scholars draw on Moiseev's work to rethink Russia's development: Elena Glushenkova, Ekopolitologiia N. N. Moiseeva i ustoichivoe razvitie Rossii (N. N. Moiseev's Eco-political Approach and Sustainable Development of Russia) (Moscow, 2015). Major memorial conferences marking anniversaries of Moiseev's birth were convened by the Moscow State University (2007) and the Trapeznikov Institute of Control Problems at the Russian Academy of Sciences (2017), not to count the many events 
Fascinating as it is in its own right, this Soviet extension of Vernadskii's theory of the biosphere and noosphere to actual environmental governance is also relevant for the comparative intellectual history of global modeling. However, this case has even broader significance, because it offers important insights into a conceptual shift in the understanding of what it means to govern in both East and West. This shift, as explicated by Moiseev, took place as a reorientation from the cybernetic theory of predictive control to governance as guidance through milieu.

Historians of science and technology have detailed the revolutionary impact of cybernetics as it emerged in the 1940 s and spread widely across different natural and social sciences from the 1950 s onwards. Briefly, the cybernetic theory of control approached the governance of behavioral systems as an informational process: a desirable state of a governable system (a target) is identified. Then, the path for reaching this target is decided upon on the basis of observation of the actual behavior of the system, which is done through feedback loops, as well as anticipation of its future behavior. Cybernetic control theory was applied to both the study and the engineering of integral, hybrid systems that could incorporate men, machines and biological processes. ${ }^{12}$ However, there were limits to the scalability of cybernetic control: the nascent Earth system science could not rely solely on the cybernetic control theory to conceptualize and steer human intervention in global change. The problem of shooting an agile enemy bomber during World War II, which had given rise to cybernetics, was a very different problem from the challenge posed by the accumulation of carbon dioxide and slow melting of glacial ice. The control of long-term and large-scale processes was of a different order, as its scale exceeded the frameworks of human time. In this case, the horizons of change stretched from several decades to hundreds or thousands of years. This new problem of large-scale,

organized by the International Independent Ecological-Political University in Moscow, that was cofounded by Moiseev and Nikolai Reimers in 1992.

12 James Beniger, The Control Revolution: Technological and Economic Origins of the Informational Society (Cambridge, MA 1989); Peter Galison, "The Ontology of the Enemy: Norbert Wiener and the Cybernetic Vision," Critical Inquiry 21/1 (1994), 228-66; Slava Gerovitch, From Newspeak to Cyberspeak: A History of Soviet Cybernetics (Cambridge, MA, 2002); David Mindell, Between Human and Machine: Feedback, Control, and Computing before Cybernetics (Baltimore, 2002); John Agar, The Government Machine: A Revolutionary History of the Computer (Cambridge, MA, 2003); Eglè Rindzevičiūte, "Purification and Hybridisation of Soviet Cybernetics: The Politics of Scientific Governance in an Authoritarian Regime," Archiv fur sozialgeschichte 50 (2010), 289-309; Andrew Pickering, The Cybernetic Brain: Sketches of Another Future (Chicago, 2009); Eden Medina, Cybernetic Revolutionaries: Technology and Politics in Allende's Chile (Cambridge, MA, 2011); Robert Kline, The Cybernetics Moment, Or, Why We Call Our Age the Information Age (Baltimore, MD, 2015); Clifford Siskin, System: The Shaping of Modern Knowledge (Cambridge, MA, 2016). 
long-term and complex change called for revision of the intellectual apparatus of governance. Alternative approaches to cybernetic control had to be developed. As a result, the problem of governing the global Earth system came to be addressed through complexity science, evolutionary biology, and emerging approaches to resilience that operated with the notion of guidance. These concerns, but also conceptual approaches, began to shape social sciences as well, particularly through explorations of biopolitics and governance through milieu in liberal governmentality studies.

The idea that governance through milieu constitutes a new form of state intervention in the fields characterized by great complexity and uncertainty, such as population, was proposed by Michel Foucault in his lectures at the Collège de France. ${ }^{13}$ With governance through milieu Foucault tried to capture those forms of steering and control which did not seek to influence individuals as units, but rather focused on their "environment." Here the environment referred to material systems of relations, which these individuals were embedded in and functionally dependent upon. ${ }^{14}$ In doing this, Foucault himself borrowed the concept "milieu" from Georges Canguilhem. According to Canguilhem, the contemporary notion of milieu refers to relationality itself, where it is impossible to separate the object from its environment. ${ }^{15}$ Since the 1980 s, Foucault's idea of government through milieu inspired several influential research agendas: Foucauldian scholars historicized colonial attempts to use different milieus, or complex material and institutional infrastructures, to control at a distance those colonial subjects who were deemed unable to reflexively govern themselves. ${ }^{16}$ Urban sociologists and media theorists focused on infrastructural milieus' effects on social and political practices. ${ }^{17}$ Environmental sociologists and historians created a new term, "environmentality," to analyze the emerging global climate governance. ${ }^{18}$ While these government-through-milieu studies developed in

13 Michel Foucault, Security, Territory, Population: Lectures at the Collège de France 1978-1979 (Basingstoke and New York, 2009), 20-21, 23.

14 For Canguilhem's influence see Jennifer Gabrys, Program Earth: Environmental Sensing Technology and the Making of a Computational Planet (Minneapolis, 2016).

15 Georges Canguilhem, "The Living and Its Milieu" (trans. from the French, originally published in 1952), Grey Room 3 (2001), 7-31.

16 Tony Bennett, Making Culture, Changing Society (London, 2013); Tony Bennett, Fiona Cameron, Nélia Dias, Ben Dibley, Rodney Harrison, Ira Jacknis, and Conal McCarthy, Collecting, Ordering, Governing: Anthropology, Museums, and Liberal Government (Durham, NC and London, 2017).

17 Gabrys, Program Earth.

18 Timothy W. Luke, "On Environmentality: Geo-power and Eco-knowledge in the Discourses of Contemporary Environmentalism," Cultural Critique 31 (1995), 57-81; 
disparate fields, they share a focus on the governmental effects of different types of material milieus, be they urban architecture, roads or digital networks.

This article argues that Moiseev's thought forms a particularly important part of the global history of Earth system governmentality, because it bridges the histories of cybernetics and systems analysis on the one side, and the histories of authoritarian, liberal and infrastructural governance on the other side. Following the outline of Moiseev's intellectual biography, the main part of the article details how computer-based policy sciences shaped the epistemological framework of late Soviet thought on Earth systems governance (what Moiseev would have identified with the noosphere). The article concludes with a discussion of the transformation of the notion of governance from purposive control to guidance through milieu, detailing how Moiseev sought to reconcile his ideas of global governance with the "really existing" Soviet authoritarian government.

\section{AN INSTITUTIONAL ENTREPRENEUR OF COMPLEX SYSTEMS}

To trace the biography of Moiseev, a scholar who bridged different political regimes, social worlds and scientific disciplines, is to trace central shifts in governance in the twentieth century. The story of Moiseev is the story of the Communist Revolution and Russian nationalism rooted in an imperial past, but also of technoscientific modernity, based on postpositivist epistemology and global thinking. It is also a story of the search for political rationality and control with the help of the instruments of technoscience, leading to fundamental revision of what it means to be rational. To do justice to the personality of Moiseev is therefore beyond the limits of this article; I only introduce briefly his intellectual and political trajectory.

Born in Moscow in 1917, Moiseev grew up in a noble family, the legacy of which, as he detailed in his memoirs, was expressed in his distaste for the Communist Party, although Moiseev passionately endorsed the socialist principle of social equality. Moiseev's maternal grandparents died in cholera epidemics and his mother was adopted by a noble industrialist, railway owner Nikolai Karlovich von Mekk. Nikita Moiseev's father, Nikolai Moiseev, graduated in law from Moscow State University (MGU), was keenly interested in economics and statistics, and studied Japanese language and economics as a diplomat in Tokyo, Japan. The Moiseev family suffered Stalin's repressions: the adoptive grandfather was shot in 1929 and Moiseev's father was killed in Butyrki prison in 1931. However, Moiseev joined the Communist Party during World War II, motivated by his patriotic

Arun Agrawal, Environmentality: Technologies of Government and the Making of Subjects

(Durham, NC, 2005). 
feelings to Russia rather than to the Party. ${ }^{19}$ In his memoir Moiseev reflected extensively on his relation to Soviet Russia, trying to reconcile his interest in science and service to the state with his painful family history. ${ }^{20}$

As a child, Moiseev attended the mathematical seminars for talented children organized by Israel Gel'fand at the prominent Steklov Institute; he won a national competition in mathematics and passed the exams for the Department of Mathematics and Mechanics of MGU. However, Moiseev was refused a place on the course because of his bourgeois background; only thanks to Gel'fand's personal support was Moiseev eventually enrolled at the university, from where he graduated in $1941 .^{21}$ In 1941 Moiseev was recruited to the army, appointed as an engineer to the air force, and sent to the front line.

After the war, in 1948-9 Moiseev was employed in the military-industrial complex specializing in rocket technology: as a senior engineer he worked on dynamics and ballistics at the missile design institute NII-2 of the Ministry of the Aviation Industry and taught the dynamics of guided missiles at the Bauman Moscow State Technical University, where he met some of the key scientists behind the Soviet space program, such as Iurii Pobedonostsev, Sergei Korolev and Vladimir Chelomei. ${ }^{22}$ However, in 1949 the Moiseev family were again repressed: his elderly stepmother was arrested, Moiseev was fired and he fled from Moscow in 1950, finding shelter in the Rostov State University, where he taught hydromechanics. Only at the beginning of the Thaw in 1956, when Stalin's terror and personality cult were rejected, could Moiseev return to Moscow. The influential academician Mikhail Lavrent'ev, the founder of the principal Soviet science city, Akademgorodok, in Novosibirsk, invited Moiseev to become a professor and dean at the Department of Control and Applied Mathematics (which trained specialists for the Soviet space program) at the Moscow Physics-Technical Institute (MFTI). In the same year, Moiseev was appointed as a researcher at the Computer Center of the Soviet Academy of Sciences, where he would work for more than three decades. ${ }^{23}$ In 1966 Moiseev

19 Nikita N. Moiseev, Kak daleko do zavtrashnego dnia ... Svobodnye razmyshleniia 19171993 (How Far Away Is Tomorrow ... Free Reflections 1917-1993) (Moscow, 2002; first published 1993), 148, 331. Petrov, Nikita Nikolaevich Moiseev.

20 Moiseev, Kak daleko, 339.

21 Ibid., 22, 111.

22 For more on Soviet space program see Asif Sidiqqi, The Red Rocket's Glare: Spaceflight and the Russian Imagination, 1857-1957 (Cambridge, 2010); Slava Gerovitch, Voices of the Space Program: Cosmonauts, Soldiers, and Engineers Who Took the USSR into Space (London, 2014).

23 Moiseev, Kak daleko, 25-28; Nikita N. Moiseev, Izbrannye trudy (Selected Works) (Moscow, 2003), 261. Moiseev retired from the Computer Center in 1987, but served as a member of the center's directors' board, alongside several other high governmental posts, until 2000. 
became a corresponding member of the Soviet Academy of Sciences (full member in 1970) and he was appointed a vice director for research of the Computer Center in 1967. Moiseev's scientific contribution to the Soviet military-industrial complex, particularly space, aviation and nuclear programs (from 1956 he had clearance to access high-level classified data), and his unparalleled social skills, propelled him into the position of research director at the Computer Center in the Soviet Academy of Sciences. The Computer Center became established as the leading research center in computer science, applied mathematics and automation, providing support, for instance, for Pavel Sukhoi's jet fighter design lab.

In addition to tapping into the Cold War arms race, Moiseev's career coincided with the opening of the Soviet system to the West and Prime Minister Kosygin's call to introduce scientific forecasting to Soviet planning and management. ${ }^{24}$ Here Moiseev bridged academia and government by initiating several strategically important and intellectually innovative fields: operations research, the systems approach and, from the 1970s, computer-based modeling of complex environmental and socioeconomic processes. Having established a solid reputation as an applied mathematician, Moiseev worked closely with several founding figures of innovative research institutions, such as Lavrent'ev; scholars working in diverse fields falling under the umbrella term of cybernetics, including the influential mathematician Aleksandr Lyapunov, who taught Moiseev mathematics at university in the 1930s, and with whom Moiseev had a long-lasting friendship; and Viktor Glushkov, who would launch the ambitious but unsuccessful program of the all-union computer network. ${ }^{25}$ Fluent in French (he also read English), Moiseev traveled abroad and actively forged links with leading Western scholars. These trips inspired Moiseev to integrate Vernadskii's theory of the biosphere and noosphere with computer-based control sciences.

The 1960s were characterized by continued technoscientific optimism, but also by growing awareness of the ineffectiveness of Soviet planning, stalling

24 Egle Rindzevičiūte, "A Struggle for the Soviet Future: The Birth of Scientific Forecasting in the Soviet Union," Slavic Review 75/1 (2016), 52-76.

25 For Moiseev's links with mathematical economics see Ivan Boldyrev and Olessia Kirtchik, "The Cultures of Mathematical Economics in the Postwar Soviet Union: More Than a Method, Less Than a Discipline," Studies in History and Philosophy of Science Part A 63 (2017), 1-10. For Lavrent'ev's role in the modernization of Soviet science see Ksenia Tatarchenko, "Calculating a Showcase: Mikhail Lavrentiev, the Politics of Expertise, and the International Life of the Siberian Science-City," Historical Studies in the Natural Sciences 46/5 (2016), 592-632. For Moiseev's correspondence with Lyapunov see the Open Archive of the Siberian Branch of the Russian Academy of Sciences, fund of A. A. Lyapunov, odasib.ru. For Gluskhov see Benjamin Peters, How Not to Network a Nation: The Uneasy History of the Soviet Internet (Cambridge, MA, 2016). 
economic growth, concern with the environment and increasing pollution. ${ }^{26}$ Moiseev encountered the emerging "integrative imagination" of environmental change as a mathematician specializing in control processes. The idea of the environment as a system of relations which is changing and needs to be explained, and not just a context that can be used to explain changes in organisms, emerged after 1948 in the writings of William Vogt and Fairfield Osborn. In 1955, a WennerGren symposium Man Changing the Face of the Earth consolidated what would become environmental thinking as a form of concern about global, long-term and future-oriented changes. The term "environment" entered policy use in 1957 when the British governmental science adviser Solly Zuckerman proposed the notion of the "environmental sciences." 27 The development of scientific environmental thinking was somewhat delayed in the Soviet Union, but Moiseev's writings reveal similar concerns to those of the systems scholars Donella and Dennis Meadows, the polymath James Lovelock and the economist Kenneth Boulding, to mention but a few Earth system thinkers, who crossed disciplinary boundaries to conceptualize coevolving Earth and human systems in the 1970s-1980s. However, in contrast to the Meadows, Lovelock and Boulding, Moiseev distinctively focused on the epistemology of governance and control.

By the 1960 s the Soviet policy science community was ready to embrace the environmental turn not only because they were concerned with pollution and the preservation of nature. Soviet scholars were also attracted to the idea of the environment as a hybrid system, which integrated human and nonhuman actors. Conceived as part of the environmental system, society and human behavior could be explored scientifically outside Marxist-Leninist dogmas. ${ }^{28}$ To define the communist society as "Earth's living matter" in effect meant to depoliticize the social. Of course, such depoliticization offered only a relative freedom: scientists experienced many institutional obstacles accessing data and providing direct input in policy making. For instance, from the early 1960 s the Soviet government invested heavily in the economic applications of mathematics. A specialist in dynamic programming and optimization of decision making in technical systems, Moiseev was enthusiastic about applying his expertise to economic planning and began to advise the State Planning Committee (Gosplan) regarding the

26 Vladislav Zubok, A Failed Empire: The Soviet Union in the Cold War from Stalin to Gorbachev (Chapel Hill, 2009); Charles Ziegler, Environmental Policy in the USSR (Amherst, 1987).

27 Paul Warde and Sverker Sörlin, "Expertise for the Future: The Emergence of 'Relevant Knowledge' in Environmental Predictions and Global Change, c.1920-1970," in Jenny Andersson and Eglè Rindzevičiūtè, eds., The Struggle for the Long Term in Transnational Science and Politics during the Cold War (New York, 2015), 39-62.

28 Joan DeBardeleben, The Environment and Marxism-Leninism: The Soviet and East German Experience (Boulder, CO, 1985); Oleg Ianitskii, "Environmental Sociology Yesterday and Today," Sociological Research 33/1 (1994), 7-32, at 9. 
development of social indicators of economic growth. However, Moiseev soon realized that Gosplan based the planning process not so much on scientific expertise, but on political negotiation and ritual. ${ }^{29}$ Furthermore, not only was the quality of the economic statistics data poor, but also access to it was very limited. Most importantly, Moiseev became convinced that the economy was too complex to be mathematized: that the very assumption of regular economic development and planning (in Russian planomernoe razvitie) was conceptually erroneous. Quantitative policy science alone, argued Moiseev, could not guarantee efficient governance of the national economy, be it communist or capitalist.

Moiseev crystallized this view during his visits as a guest professor at Yale University, where he was invited by the economist and, later, Nobel Prize winner Tjalling Koopmans in 1974 and $1976 .^{30}$ In a paper presented for the Yale faculty, Moiseev proposed the idea of the ultimate ungovernability of economics. Just like Norbert Wiener, Moiseev argued that socioeconomic processes were far too complex to be captured by existing computer modeling techniques. ${ }^{31}$ Moiseev even suggested that the term "planned economy" was an oxymoron. He proposed to use the term "guided economy" instead of governed (or controlled) economy (napravliaemaia ekonomika instead of upravliaemaia ekonomika in Russian). Koopmans, reportedly, "did not like this paper at all," and Moiseev became apprehensive about the possible political consequences of his talk. He was relieved to find out later that back in Moscow "no one had even noticed it."32

In his memoir, Moiseev reported having lost his belief in the capacity of positivist science and mathematical applications to make long-term economic forecasts in the late 1960s, which is ironic, because in 1968 he co-established what would become one of the leading centers of economic modeling in the country. ${ }^{33}$ Convinced that the growth of scientific expertise increases the rate of change in socioeconomic systems (increasing availability of knowledge makes decision making harder rather than easier), Moiseev turned to the issues of complexity, evolution and self-organization. Considering that policy sciences could be more fruitfully applied to environmental problems than to economic

29 For ritualistic scientific expertise in Soviet planning see Peter Rutland, The Myth of the Plan: Lessons of Soviet Planning Experience (London, 1985).

3o On Koopmans's links with Soviet science see Till Düppe, "Koopmans in the Soviet Union: A Travel Report of the Summer of 1965," Journal of the History of Economic Thought 38/1 (2016), 81-104.

31 Norbert Wiener, Cybernetics; Or, Control and Communication in the Animal and in the Machine (Cambridge, MA, 1965), 25.

32 Moiseev, Kak daleko, 193-5.

33 Boldyrev and Kirtchik, "The Cultures of Mathematical Economics," 7; Nikita Moiseev, Prosteishiie matematicheskie modeli ekonomicheskogo prognozirovaniia (Basic Mathematical Models of Economic Forecasting) (Moscow, 1975). 
ones, he began to develop computer-based modeling of the biosphere and to rethink the fundamentals of governability and control. ${ }^{34}$

Moiseev did not develop these ideas in isolation: encounters with Vernadskiian scholars and links with Western scientists were vital. For instance, when Moiseev visited a French research center dedicated to the management of large technical systems in Fontainebleau near Paris, he stayed in the Latin Quarter, drove a small Renault, read Friedrich Hayek's The Road to Serfdom in French, and regularly met with Russian expatriate intellectuals, such as the Russian microbiologist Sergei Vinogradskii's daughter, who met Vernadskii in Bergson's seminars in Paris. ${ }^{35}$ Moiseev participated in major East-West cooperation schemes, such as the Man and Biosphere UNESCO program launched in 1971, events organized by the Club of Rome in relation to its first report The Limits to Growth (1972), the International Institute of Applied Systems Analysis (IIASA, established in Laxenburg, Austria, in 1972) and the Paris Institut de la vie, founded by the French policy activist Maurice Marois in 1971. Having initiated one of the first Soviet computer laboratories modeling geophysical and biological processes in land, ocean and atmosphere at the Computer Center, Moiseev had contacts with climate research centers at Livermore and the University of Oregon, USA. Finally, under the auspices of the International Council of Scientific Unions (ICSU), Moiseev participated in the follow-up study of the environmental consequences of nuclear war in 1983-5.

From the early 1970s, Moiseev published widely on the applications of policy sciences for economic and organizational planning, drawing on theoretical advances in cybernetics and systems analysis. ${ }^{36}$ His later work drew inspiration from Vernadskii's writings on the biosphere and noosphere, resulting in the publication of Man, Society, and the Environment (1980), Man and Biosphere (1985) and The Algorithm of Development (1987). The last book, which was reworked

Moiseev, Kak daleko, 230; Nikita Moiseev, Chelovek i noosfera (Man and Noosphere) (Moscow, 1990), 269-70.

35 In his memoir Moiseev dates this trip to 1959, although he mentions meeting Rudolf Kalman, which makes it more likely to be the late 196os. Although Moiseev noted reading Hayek as a significant event, he did not engage with Hayek's theory of a centrally non-governable economy in his writings. Instead, Moiseev often referred to the Russian organization theorist Aleksandr Bogdanov, who proposed that any governmental apparatus must be regularly decentralized. It is clear, though, that Hayek's neoliberal ideas had appeal for policy scientists interested in complexity. For Hayek's intellectual affinity with the resilience approach see David Chandler, Resilience: The Governance of Complexity (London, 2014).

36 Moiseev had close links with some of the leading cyberneticians: he copublished with Alexei Rumiantsev, and Sergei Sobolev was the opponent of Moiseev's doctoral dissertation. Moiseev's key publications from this period are On the Theory of Optimal Systems (1975); Methods of Optimization (1978); and Mathematics, Governance and Economics (1970). 
into Man and Noosphere, and printed in a 100,000-copy run in 1990, argued that governability and control were central intellectual issues in the age of mankind as a geological force.

Moiseev was by no means alone in the emerging field of Earth system governance in the Soviet Union: he drew on the work of the leading atmosphere and climate engineering scientist Mikhail Budyko, who significantly advanced biosphere thinking into what was then a nascent global ecological science. ${ }^{37}$ The prominent geophysicist Evgenii Fedorov's writings on the interaction between man and biosphere as a social and governmental issue formed another important influence. ${ }^{38}$ Moiseev's competence in mathematical modeling also helped him to forge interdisciplinary links: according to Douglas Weiner, by the mid-1970s mathematical methods had become the dominant approach in Soviet environmental and ecological science, promoted by scientists following Timofeev-Resovskii's intellectual lineage. However, there were important political cleavages among the pioneers of mathematized environmental governance. Some environmental scientists, such as Stanislav Shvarts and Evgenii Fedorov, were strongly committed to the centralist, scientific projects of the transformation of nature, while others, such as Nikolai Reimers and Moiseev, were deeply skeptical about it. ${ }^{39}$ Unlike ecologists, who were interested in preservation, Moiseev sought to extend mathematical insights into self-organization to the governance of the biosphere. Initially this intellectual pursuit fell on deaf ears: Moiseev wrote that even bright mathematical biologists, like Svirezhev, and mathematical cyberneticians, like Lyapunov, did not appreciate his interest in the epistemology of the governability of the complex organization of the biosphere..$^{40}$

Moiseev's breakthrough came during the escalation of the Cold War under Ronald Reagan in 1983, when Moiseev became widely known as the patron of the Soviet study of the environmental effects of nuclear war. In 1982 Paul Crutzen and John Birks formulated the hypothesis that a nuclear exchange would cause a global darkening and cooling. This hypothesis was tested jointly by US-Soviet scientists who simulated several scenarios of the environmental consequences of nuclear war on the general circulation models (GCMs) of global climate in 1983. These simulations confirmed the hypothesis of nuclear winter and the less harsh

Mikhail Budyko, Global Ecology (Moscow, 1977); Jonathan Oldfield, "Mikhail Budyko's (1920-2001) contributions to Global Climate Science: From Heat Balances to Climate Change and Global Ecology," WIREs Climate Change 7/5 (2016), 682-92.

38 Evgenii Fedorov, Vzaimodeistvie obshchestva i prirody (The Interrelation between Society and Nature) (Leningrad, 1972); Fedorov, Ecological Crisis and Social Progress (Moscow, 1977). On Fedorov's thought about global environmental systems see Julia Lajus, ongoing.

39 For an overview of Soviet scientific ecology's shift toward mathematization see Weiner, $A$ Little Corner of Freedom, 384-9.

40 Moiseev, Kak daleko. 
scenario, nuclear autumn, where the northern hemisphere would experience less devastating cooling. In both cases the study established that nuclear war would cause irreversible climate change. Led by Moiseev, the Soviet team gathered such leading scientists as atmosphere physicists Georgii Golitsyn and Vladimir Aleksandrov, climatologist Mikhail Budyko, and population biologist Iurii Svirezhev.

The nuclear winter study influenced nuclear strategy, disarmament and Earth system science, but can also be argued to have contributed to the development of Moiseev's concept of the noosphere, where the biosphere can become governable once the principle of governance through milieu is applied, and Crutzen's concept of the epochal change to the Anthropocene. ${ }^{41}$ Indeed, both the noosphere and the Anthropocene are epochal and analytical concepts, as they indicate a historically changing relationship between mankind and the Earth. The key difference between these terms is that Crutzen's Anthropocene sought to draw attention to scientific evidence of humanity's geological impact on the planet (he was not the first to propose this), whereas Moiseev borrowed Vernadskii's concept of the noosphere to explore the potential and limit of the application of policy sciences on the global level. It is important to add, however, that both Crutzen and Moiseev called for the renewal of a global governmental agenda. For instance, in his seminal article Crutzen connected the Anthropocene with the control revolution, the rise of automation since James Watt's invention of the steam engine, writing that control is the key problem posed by this new era: "a daunting task lies ahead for scientists and engineers to guide society towards environmentally sustainable management during the era of the Anthropocene." 42 It is quite remarkable that Moiseev had attempted to do just that some two decades earlier on the other side of the Iron Curtain.

From 1980 Moiseev began to popularize the global modeling of the biosphere and speak up for grave environmental problems, both in the Soviet Union and in the West. He saw this policy entrepreneurship as ushering in the noosphere, where global biospheric change becomes governable and began to engage with higher levels of politics. Moiseev's publications in influential journals paved the way for the introduction of global problems in the CPSU's program in 1985. Together with the prominent Russian physicist Evgenii Velikhov, Moiseev was appointed

${ }^{41}$ Lawrence Badash, A Nuclear Winter's Tale: Science and Politics in the 1980s (Cambridge, MA, 2009); Joseph Masco, "Bad Weather: On Planetary Crisis," Social Studies of Science 40/1 (2010), 7-40; Paul Rubinson, "The Global Effects of Nuclear Winter: Science and Antinuclear Protest in the United States and the Soviet Union during the 1980s," Cold War History 14 (2014), 47-69; Rindzevičiūtè, The Power of Systems, chap. 6.

42 Crutzen, "Geology of Mankind," 23. 
to the commission set up to clean up Chernobyl after the explosion in $1986 .{ }^{43}$ Later, Moiseev became the president of the Green Cross Russia, an international organization that was established by Mikhail Gorbachev in 1993 to deal with the environmental consequences of military activities. Moiseev also chaired the State Council for the Analysis of Crisis Situations and was the president of the Russian National Committee for the United Nations Environment Program (UNEP). In 1995 UNEP awarded Moiseev the Global 500 Award; Paul Crutzen would receive this prize the next year.

Moiseev differed from typical Soviet science or civic activists: instead of pursuing specific issue-driven agendas, he sought to fundamentally transform the intellectual apparatus underlying global governance. His position toward the official government institutions could be described as an enterprising "reform technocrat," to borrow a phrase from David Priestland. ${ }^{44}$ Moiseev saw his duty as enlightening policy makers and facilitating new institutional designs for governing complexity, using the noosphere theory to establish conceptual and institutional links between expanding geophysical sciences and public-policy sciences. ${ }^{45}$ Accordingly, in what follows, I focus on the theory of the noosphere not so much as an instrument to legitimize environmental protection in the Soviet Union, but as part of a new complex of governance through milieu, one that required definition of new notions of rationality and control that go beyond the idea that global processes can be steered on the basis of cybernetics.

\section{TRANSNATIONAL DEVELOPMENT OF THE BIOSPHERE AND NOOSPHERE}

Although the term "biosphere" and the name of Vernadskii occasionally surfaced in specialist writings in the West, such as Eugene Odum's influential textbook Fundamentals of Ecology (1953, translated into Russian in 1968), it was only at a UNESCO conference in 1968 that the term "biosphere" was first used in the context of international science and policy. ${ }^{46}$ Since then, the development

43 Nikita Moiseev and I. T. Frolov, "Vysokoe soprikosnovenie: obshchesto, chelovek, i priroda v vek mikroelektroniki, informatiki i biotekhnologii” (Prominent Encounter: Society, Man and Nature in the Age of Microelectronics, Informatics and Biotechnology), Voprosy filosofii (The Issues of Philosophy) 9 (1984), 24-41.

44 For scientific and civic activists in the Soviet Union see Weiner, A Little Corner of Freedom, 12-14; David Priestland, Merchant, Soldier, Sage: A New History of Power (London, 2012).

45 Those few of Moiseev's publications that are available in English lack the lucidity of argument and engaging style that characterize Moiseev's writings in Russian. Nikita Moiseev, "A New Look at Evolution: Marx, Teilhard de Chardin, Vernadsky," World Futures 36/1 (1993), 1-19.

46 Oldfield and Shaw, "V. I. Vernadskii," 299. 
and spread of the biosphere concept have been documented in many histories of the geosciences, but it is less widely known that the concept of the biosphere also entered management and policy sciences, in parallel with the rise of the systems approach, a transdisciplinary science of organization that rose to prominence in the East and West from the late 1960s. ${ }^{47}$

The concept of the biosphere was introduced into Soviet policy discourses and systems thinking in the late 1950s. Vernadskii's ideas inspired different scholars, ranging from climate science (Mikhail Budyko, Evgenii Fedorov) and soil science (Viktor Kovda, with whom Moiseev was in a close professional relation) to anthropology (Lev Gumilev, with whose interpretation of the noosphere Moiseev strongly disagreed). ${ }^{48}$ For Moiseev the central figure was the geneticist Nikolai Timofeev-Resovskii, who was based in the secret science city of Obninsk, home to the world's first commercial nuclear power plant, and who was among the first ones to revive Vernadskii's theory of the biosphere after the end of the Stalinist era in 1956. Moiseev met Timofeev-Resovskii through the mathematical biologist Iurii Svirezhev; this encounter led to regular meetings-turned-informalseminars in Moiseev's office, which often ran late into the evening. Discussions with Timofeev-Resovskii not only enthused Moiseev to develop computer applications for modeling interactions among geophysical and living systems, but also facilitated Moiseev's friendship with Kovda, an influential Soviet Russian scientist who was involved in the setting up of the Man and the Biosphere UNESCO program. ${ }^{49}$

In addition to biologists and pedologists, Moiseev fostered relations with scholars at the Central Geophysical Laboratory in Leningrad, the Institutes of Oceonography and Geography, and MGU. His networks did not stop at the Iron Curtain: Moiseev met Jay Forrester and Dennis Meadows at the first UNESCO Conference on Global Problems in Venice, Italy, in 1971. Capitalizing on the momentum in the wake of the Venice conference and the subsequent publication of The Limits to Growth (1972), Moiseev obtained a grant to create two laboratories for mathematical modeling of the biosphere, which were awarded by the chairman of the section of Earth Sciences at the Soviet Academy of Sciences, Aleksandr Sidorenko. This institutional innovation must be seen in both domestic

47 Beryl Radin, Beyond Machiavelli: Policy Analysis Comes of Age (Washington, DC, 200o); Hunter Heyck, Age of System: Understanding the Development of Modern Social Science (Baltimore, 2015); Rindzevičiūtè, The Power of Systems.

48 Mark Bassin, The Gumilev Mystique: Biopolitics, Eurasianism, and the Construction of Community in Modern Russia (Ithaca, 2016).

49 Marc Elie, "Formulating the Global Environment: Soviet Soil Scientists and the International Desertification Discussion, 1968-91," Slavonic and East European Review 93/1 (2015), 181-204. 
and international political contexts: while the Soviet Union began to actively brand its foreign policy with global environmental concerns, such prominent scientists as Budyko and Fedorov began to publish specialist and popular books on the global environmental crisis. The emerging computer-based global modeling was an important nexus that bridged techno-optimism and global concerns. For instance, in his long afterword for Forrester's World Dynamics (published in Russian in 1978), Moiseev declared that computer simulation of complex biosphere processes could provide a scientific foundation for world government. ${ }^{\circ}$ The Russian translation of World Dynamics resonated widely: Moiseev's name became familiar in the circles of cultural and environmental dissidents. ${ }^{51}$

Having borrowed Vernadskii's idea of mankind as a geological force and inspired by Vernadskii's vision of the noosphere where scientific reason would organize planetary development, Moiseev operationalized Vernadskii's geophysical philosophy to rethink the wider governmental implications of mathematical methods, drawing on insights from OR, systems theory, computerbased modeling, ecology and climate science. In his writings, Moiseev used the terms "biosphere" and "noosphere" often interchangeably, but generally by "noosphere" he referred to the near future when the application of policy sciences to global planetary governance would be possible both conceptually and institutionally. First and foremost, Moiseev was interested in the applied mathematical side of rational planetary governance: here Moiseev was deeply influenced by Henri Poincarés work on differential equations. Indeed, mathematical thinking about parameters and limits led Moiseev to define governmental rationality as thinking from the limits, rather than as a maximizing or optimizing process. ${ }^{52}$ Moiseev also read Teilhard de Chardin's The Human Phenomenon and was familiar with James Lovelock's Gaia theory, which was first formulated in the 1960s; indeed, the first computer-based modeling system of global ecology at the Computer Center was called "Gaia" in the early 1980 s. $^{53}$ Moiseev certainly knew work by Paul Erlich, a US biologist and active publicpolicy lobbyist who popularized the term "coevolution" in the West in the late 1960s; these two scientists met through the nuclear winter project in the early

50 Nikita Moiseev, “'Mirovaia dinamika’ Forrestera i aktual'nye voprosy mirovoi evoliutsii” (Forrester's World Dynamics and Important Questions of World Evolution), in Jay Forrester, Mirovaia dinamika (World Dynamics) (Moscow, 1978), 264-90.

51 Moiseev's afterword inspired the prominent dissident Viacheslav Igrunov to organize an alternative department of the Club of Rome in Russia. Viacheslav Igrunov, "O Nikite Nikolaiche Moiseeve i o tom, kak nesostoialsia Moskovskii Rimskii klub," igrunov.ru.

52 Moiseev, Chelovek i noosfera.

53 Nikita Moiseev, Vladimir Aleksandrov and Aleksandr Tarko, Chelovek i biosfera (Man and the Biosphere) (Moscow, 1985), 5; Moiseev, Chelovek i noosfera, 235. 
$1980 s .{ }^{54}$ While coevolution was defined by Erlich and Peter Raven as a reciprocal change in the interaction of different species, Moiseev extended this definition to embrace the coevolution of living and non-living matter. ${ }^{55}$ In addition to Dokuchaev, Bogdanov, Vernadskii and Teihard du Chardin, important influences were Budyko's and Federov's writings on global climate, Kovda's writings on waste, Piotr Anokhin's work on biological cybernetics, and Ivan Schmalhausen's work on evolution, all of which Moiseev put in dialogue with ideas on changing systems and self-organizing order developed by such scientists as molecular biologist Manfred Elgen, energy dissipation theorist Lars Onsager, and, obviously, Norbert Wiener's cybernetics. Furthermore, Moiseev touched upon debates in political economy by Adam Smith, David Ricardo, Vilfredo Pareto and, at a later stage, Hayek. Although Moiseev paid dues to dialectical philosophy, making occasional references to Karl Marx and Hegel, he made it clear that Marxist approaches were insufficient to understand the complexity of global coevolution. In many ways, then, Moiseev's style of thinking was close to synergetics, but his originality was in cross-fertilizing ideas from different fields to redefine the notion of global governance, which is considered in the next section.

\section{POST-CYBERNETIC GOVERNANCE OF THE GLOBAL BIOSPHERE}

In the 1980 s Moiseev joined the ranks of scholars alerting governments to the fact that the coevolution of the man and the biosphere could not be left ungoverned: mankind's activities had become such a significant factor that the whole biosphere was deteriorating, facing the risk of nuclear war, industrial accidents, pollution and, ultimately, carbon dioxide-induced climate change, while growing production and consumption was causing depletion of global resources. ${ }^{56}$ In order to address these complex issues from the perspective of cybernetic predictive rationality, one has to identify a desirable state of the global system, establish policy targets, and allocate pathways for achieving those targets by optimal control methods. However, such an intellectual model of steering can only be applied to relatively stable and simple systems. In contrast, change in the global biosphere is driven by complex, contingent factors that affect different

54 Thomas Robertson, "Revisiting the Early 1970s Commoner-Erlich Debate about Population and Environment: Dueling Critiques of Production and Consumption in the Global Age," in Heinrich Hartmann and Corinna Unger, eds., A World of Populations: Transnational Perspectives on Demography (New York, 2014), 108-25, at 109.

55 Paul Erlich and Peter Raven, "Butterflies and Plants: A Study in Coevolution," Evolution 18/4 (1967), 586-608, at 606; Andrei Lapenis, "Directed Evolution of the Biosphere: Biogeochemical Selection or Gaia?", Professional Geographer 54/3 (2002), 379-91, at 380.

56 Moiseev, Chelovek i noosfera, 10-11. 
scales of the system differently. Causal mechanisms at the micro level are often decoupled from processes at the macro level: for instance, the individual behavior of an animal does not explain the collective behavior of a pack of animals, because the two are different systems. While the planetary system is highly regular and predictable, many subsystems of the Earth, such as the weather, or human economies and societies, are not predictable in the long term. ${ }^{57}$

Could global Earth governance ever be rationalized? According to Moiseev, it is only possible if we use a particular concept of governance and rationality. Mankind's role as a geological force, argued Moiseev, can be theorized as a process of self-organization, where living and non-living natural components intertwine and shape each other. In this process, wrote Moiseev, the ontological distinction between man and nature becomes redundant. Accordingly, the science of the global biosphere should approach changes in society and nature not as a clash between two essentially different systems, but as the coevolution of particular organizational forms..$^{8}$ Proposing that "organization" is a fundamental concept just like "energy" and "matter," Moiseev defined organization as stabilization, a condition where variables are conservative and change slowly. ${ }^{59}$ In other words, things that change more slowly are more "organized." Mankind's role on Earth, then, is to become a wise and responsible organizer, to slow down the global environmental changes that are spurred by human activities. Equipped with scientific data, methods and computer technology, man could become "a master of the biosphere," but not in the sense that man would finally "conquer nature" (a popular trope of the Soviet discourse of progress). Man would become a manager, able to "consciously use the resources of the planet in order to guarantee the conditions for co-evolution." "In this way, Moiseev proposed that it would be intellectually consistent to base the principles of the governance of global development not on acceleration and growth, but on slowing down the rate of change. In doing this, mankind could no longer rely on self-organization through adaptation to the changing environment, because the environment had begun to change in such a way that adaptation was not a viable strategy anymore. Therefore adaptation, which Moiseev termed "the strategy of nature," must be replaced by "a strategy of Reason," a new mentality of governance based on a qualitatively different scientific definition of what can be considered as rational and effective control. ${ }^{61}$

Ibid., 55 .

Ibid., 141.

Ibid., 61.

Moiseev, Aleksandrov and Tarko, Chelovek i biosfera, 11.

Moiseev, Chelovek i noosfera, 7. 
First, in order to think meaningfully about rational governance of the global Earth system, one must go beyond the hegemony of the cybernetic notion of purposive, teleological control. Moiseev's argument proceeds in the following way: predictive control in cybernetic engineering systems is only possible under conditions where the purpose of the system which is being controlled is known. Consider the classical problem of the antiaircraft defense system: if the enemy pilot's intention (target) is known, the trajectory of the plane and the missile can be predicted with a high level of certainty and the enemy bomber can be hit. However, this model of control is difficult to apply to complex systems, such as human societies, which are characterized by multiple, intertwined processes and intentions and are therefore less predictable. Different actors can evaluate the same situation differently or have contradictory goals. Even if a shared goal is agreed upon, there can be many different ways of achieving it. ${ }^{62}$ Whereas this social complexity makes teleological control mechanisms, e.g. public policy, very difficult to translate from an intellectual program into action, the geophysical complexity of the global Earth system (the interaction of the atmosphere, the ocean and the land) makes teleological control simply redundant.

The question whether the global Earth system can be described as a purposive system has actually bothered many bright minds. Some thinkers, such as James Lovelock, considered that the Earth can be seen as teleological, proposing that all ecological systems, including the planet Earth, actively seek homeostasis, a particular state of equilibrium. However, Moiseev did not believe in naturally occurring homeostasis and was highly aware of historical examples of unpredictable and catastrophic changes to biospheric systems. According to Moiseev, the very idea of equilibrium promised a false hope of control and was dangerous, because it obscured the fact that human activities impacted geophysical processes in nonlinear ways, which could never be fully understood. The outcomes of interventions into the biosphere could never be predicted with confidence over the long term. Furthermore, Moiseev argued that it is centrally important to recognize that, in the case of the Earth system, the governing bodies are not outside, but inside, the system that is being governed.

Drawing on systems theories of increasing complexity, Moiseev posited that theoretically the controlling center coevolves with the controlled system by being part of it. Controlling interventions make the system ever more complex and uncertain. ${ }^{63}$ In this way, Moiseev viewed the optimal governability of the environment significantly differently from many Soviet contemporaries. Such influential environmental scientists as Fedorov used their scientific authority to criticize the irrational use of global natural resources, at the same time

\footnotetext{
62 Ibid., 72, 84-5.

63 Ibid., 85 .
} 
carefully aligning their arguments with the ideological doctrine of the political superiority of communism and the commitment to growth. For instance, Fedorov proclaimed that the long-term global goals of world governance could only be achieved by replacing the capitalist system with a socialist society, where environmental governance could be put to optimal, rational use. ${ }^{64}$

In contrast, Moiseev argued that the political identity of the governmental system was largely irrelevant for Earth system governance. While growth, in many cases, was a problem, not a solution, the key issue was the understanding of control that had to be revised. In Soviet policy sciences "control" was defined as "purposive governance" (in Russian upravlenie): an intellectual, interventionist activity based on information. According to the ideal model of cybernetic control, any given object of control must be thoroughly examined by scientists; its behavior must be monitored, tracked and predicted. If the controlled object is a social collective, e.g. an organization, a state, a sector of the economy, then control of its behavior must be institutionalized through a centralist bureaucracy and the political Party apparatus, which sets the object's goals for the future. This cybernetic model of steering proliferated in Soviet management literature. Such diverse activities as the performative brain, a management unit in a firm, and Gosplan were described as being able to formulate goals, project them into the future and reflexively adjust the behavior of the systems under their control according to changes in the environment. ${ }^{65}$ It was precisely this intellectual model of control that formed the basis for Viktor Glushkov's project of OGAS, the all-union computerization network. ${ }^{66}$ However, in the case of the global Earth system, wrote Moiseev, there was no certain knowledge to be had, there were too many intertwined behavioral systems to control, and, importantly, there was no central authority to set the goals. What can it mean to govern the Earth system, if it is unpredictable and uncontrollable?

In response to this question, Moiseev offered what can be described as a post-cybernetic theory of governance, although Moiseev himself does not use this term. First, according to Moiseev, the institution of predictive scientific expertise remains relevant at lower scales of the Earth system: statistical forecasting can map long- and short-term consequences that could potentially destabilize the biosphere. ${ }^{67}$ At the global scale, these negative consequences must be prevented

64 Evgenii Fedorov, Man and Nature: The Ecological Crisis and Social Progress (New York, 1981), 88-99, 164.

65 Rindzevičiūte, The Power of Systems; Adam Leeds, "Dreams in Cybernetic Fugue: Cold War Technoscience, the Intelligentsia, and the Birth of Soviet Mathematical Economics," Historical Studies in the Natural Sciences 46/5 (2016), 633-68.

66 For OGAS see Peters, How Not to Network a Nation.

67 Moiseev, Chelovek i noosfera, 319. 
by establishing boundaries and thresholds to human activities, such as limits to local and aggregate levels of pollution, exploitation of resources and the extinction of species. In this way, the lower-level predictive scientific expertise forms an important basis for managing higher levels of complexity, the global scale and the long term. However, the gap between these two levels can only be bridged if the prevailing governmental attitude to precision and certainty is abandoned. The role of scientists in Earth system governance (what Vernadskii and Moiseev would describe as the noosphere: the biosphere plus governmental apparatus) is to identify basic, crude parameters that define the boundaries of global environmental change within which mankind's biological survival is possible. This sort of scientific knowledge can only be approximate, imperfect and uncertain. This is a very different requirement, if compared with the epistemological grounds for cybernetic control, which seeks to make predictions as precise as possible. For Moiseev, the crudeness of knowledge is not a problem, but an asset: it is important not to eliminate uncertainty by offering false precision.

Second, this crude, parametric knowledge of the limits must be made actionable. Positive, target-based control must be replaced with negative guidance. To govern the global biosphere, according to Moiseev, is not to govern prescriptively (do $x, y, z$ ), but to govern prohibitively (do whatever except for $x$, $y, z$ ). Here the governor does not impose a concrete goal on the governed system, but instead imposes limits through a system of prohibitions. ${ }^{68}$

Moiseev terms this type of control "guided development," one which abandons goals, intentions and informational control and is therefore different from "the control of a process" (napravliaemoe razvitie versus upravlenie processom). Moiseev employs mathematical language and hydromechanics metaphors to describe such negative guidance: he writes about "algorithms" and "channels" of development that must be used to establish not targets, but prohibitions or taboos, which would set limits to those human activities which are deemed to threaten the desirable evolution of the biosphere. Mankind, in this way, is left in principle free to formulate and pursue its many different goals, as long as their actions remain within the boundaries of given parameters. Moiseev imagined human activity to be channeled like a water stream in such a way that it does not disturb the biosphere. ${ }^{69}$

Scientific articulation and institutionalization of these thresholds serve as the epistemological foundations for a global post-cybernetic governance. The

\footnotetext{
68 Ibid., 319.

69 Ibid., 316-19. Moiseev noted that his concept of guided development is similar in principle to the prominent geographer Lev Berg's concept of "guided evolution," although Berg based his theory on completely different argumentation. Nikita Moiseev, Izbrannye trudy (Selected Writings) (Moscow, 2003), 111.
} 
intellectual purpose of the limits is not to limit the autonomy of individuals and social groups, but to serve as cognitive channels, a computer-mediated milieu, guiding pluralistic social self-organization. Limits, not targets, come first in policy decisions.

Debates on "critical thresholds" of climate change and the ensuing securitization and risk management abounded among Western climate scientists in the early $1990 .^{70}$ Moiseev saw these debates not as a mere technical quibble, but as a central component of the post-cybernetic governmentality of the noosphere. In this respect Moiseev's view is close to what Timothy O'Riordan and Steve Rayner describe as "precautionary science": government of high complexity must combine intuition and foresight rather than knowledge that claims certainty. ${ }^{71}$ However, whereas O'Riordan and Rayner promote the role of scientists as persuaders, ensuring institutional pluralism, Moiseev wanted to redefine the very notion of rationality and control and spread these new notions among a wide range of decision makers. Moiseev wanted to change the epistemological culture of global governance that mobilized the notions of intention, prediction, certainty and linear control. It is important to note that since the late 1990s policy makers' responses to uncertainty were mapped and theorized in the influential scholarship on the politics of preparedness..$^{72}$ Particularly important is the work on the adoption and implementation of the concept of resilience, developed by C. S. Holling at the East-West think tank IIASA, with which Moiseev was also closely involved, in the 1970s-1980s. ${ }^{73}$ In this context, Moiseev's efforts to develop a conceptual, technical and institutional basis for governing uncertainty at a global scale in the Soviet Union during the period when the Soviet economic system was in severe decline are indeed quite remarkable. What drove him to innovate in this way? I suggest that Moiseev's project was as much political as it was scientific.

Being experienced in both scientific research and policy, Moiseev harbored no naive hopes that Earth system science could provide certainty or that scientific

70 Angela Oels, "Climate Security as Governmentality: From Precaution to Preparedness," in Johannes Stripple and Harriet Bulkeley, eds., Governing the Climate: New Approaches to Rationality, Power and Politics (Cambridge, 2013), 197-216, at 205-6.

71 Timothy O'Riordan and Steve Rayner, "Risk Management for Global Environmental Change," Global Environmental Change 1/2 (1991), 91-108, at 103-4.

72 Stephen Collier, Post-Soviet Social: Neoliberalism, Social Modernity, Biopolitics (Princeton, 2011); Claudia Aradau and Rens van Munster, Politics of Catastrophe: Genealogies of the Unknown (London, 2011).

73 Oels, "Climate Security," 208; Isabell Schrickel, "Von Schmetterlingen und Atomreaktoren: Medien und Politiken der Resilienz am IIASA," Behemoth 7/2 (2014), 5-25; Jeremy Walker and Melinda Cooper, "Genealogies of Resilience: From Systems Ecology to the Political Economy of Crisis Adaptation," Security Dialogue 42/2 (2011), 143-60. 
experts could directly influence Soviet, or indeed any, policy decisions. He therefore never offered any "optimal solutions," particularly in the long term. Instead, Moiseev cautioned against the illusion that such solutions may exist (hence his fierce criticism of the term "sustainable development"). Instead of long-term solutions, he called for the creation of forms of long-term engagement in the process of a continuous search for compromise, a process in which globally accessible scientific expertise would be coproduced with stakeholders. New, specially designed "institutes of agreement" would have to be developed for this purpose, ideally under the auspices of the UN. ${ }^{74}$

However, this institutional change at the international level alone would not suffice: the conceptualization of governance and control must change as well. Moiseev argued that it would be impossible to define and solve the problems of the global biosphere if the underlying discourse remained based on a teleological, cybernetic notion of control and a reductionist expectation of a linear, deterministic analysis of complex processes. Nowhere could this concern be more adequately placed than in the Soviet Union, where the Party and industry leaders were blind to persuasion from below and suspicious of anybody who questioned the value of certainty and centralist leadership. Accordingly, Moiseev proposed to abandon centralist control, based on the idea (but not practice) of long-term forecasting and plans, replacing it with negative, regulatory government through taboos. Like Kenneth Arrow, Moiseev recognized that it is impossible to reach a global agreement on the target outcomes of environmental protection because of starkly different standards of living and social and political preferences. The consensus on the limits of global environmental change, however, could be achieved. The desirable target would be universally defined as a state of the biosphere that ensures human survival; its parameters would be set by Earth system scientists, engaged in cross-border cooperation in data collection and modeling, thus producing a cognitive, computer-mediated milieu for governance.

Thinking from the limits would lead to different policy solutions: Moiseev made a range of such proposals, applying post-cybernetic guidance in the areas of national security, economy and the environment, following Mikhail Gorbachev's reforms of the Soviet economy and state after $1986 .{ }^{75}$ For instance, instead of complicated institutional bargaining over the reduction of nuclear arsenals, trying to identify which types of weapon should be decommissioned first, Moiseev proposed limiting the efficiency of nuclear defense by imposing new constraints on it. All nuclear nations would cooperate, creating a vast and expensive global surveillance system, enabling all members to track the activities

\footnotetext{
74 Moiseev, Chelovek i noosfera, 275.

75 Ibid.
} 
in their nuclear sectors. A surprise launch of a nuclear missile and retaliation would become strategically impossible and nuclear weapons would eventually become obsolete. ${ }^{76}$ In the economy, Moiseev wanted to abolish "authoritarian planning," introducing market mechanisms as conductors for negative feedback in the economy. However, this liberalization would only be beneficial if limits to the markets were established, providing guidance toward socially desirable goals. ${ }^{77}$ Such negative guidance could take place on the basis of global ecological information databases, scientific projects which would be linked to the political institutes of agreement concerned with the global future. The limits for global environmental planning would be set in the light of loads that local and regional social and economic systems could bear, thus ensuring the welfare of local populations. ${ }^{78}$ For Moiseev, scientific expertise, particularly computer modeling, was vital for the establishment of such taboos or thresholds, forming a socioinformational milieu of decision making which would socialize the governing elites into these new notions of a rationality of limits and guidance.

Moiseev never detailed how this cognitive milieu could be translated into national legislation and institutions. It is clear that Moiseev avoided antagonizing Soviet political leaders, proposing what was an epistemological infrastructure for apolitical solutions to global problems. However, technical solutions have their own politics: this has been made clear in Foucauldian research on the governmental effects of material milieus, such as urban, transport and energy infrastructure, the construction of which shapes local populations. ${ }^{79}$ The next section proposes that Moiseev's governance through guidance is just such a political project of informational infrastructure.

\section{THE POLITICS OF POST-CYBERNETIC GOVERNANCE THROUGH MILIEU}

In order to be actionable upon, the complex Earth system must be subjected to a particular form of articulation, one which Theodore Porter called a "thin description," which is expressed (ideally) in a mathematical language. ${ }^{80}$ Soviet

\footnotetext{
$76 \quad$ Ibid., 305.

77 Ibid., 331-6.

78 Ibid., 340-42.

79 Thomas Hughes, Networks of Power: Electrification in Western Society, 1880-1930 (Baltimore, 1993); Gabrielle Hecht, The Radiance of France: Nuclear Power and National Identity after World War II (Cambridge, MA, 1998); Andrew Barry, Political Machines: Governing a Technological Society (London and New York, 2001); Paul Edwards, A Vast Machine.

80 Theodore Porter, "Thin Description: Surface and Depth in Science and Science Studies," Osiris 27/1 (2012), 209-26.
} 
global modelers had long argued that those computer simulations which seek to represent the full complexity of geophysical and anthropogenic processes were useful only for scientific heuristic purposes, not for policy decisions. ${ }^{81}$ As O'Riordan and Rayner would later observe, the method of computerbased modeling uses a simplified system of discrete elements, which does not replicate faithfully the complex character of the biosphere. ${ }^{82}$ The simplicity and reductionism of global models, wrote Moiseev, does not necessarily produce erroneous results: the data is but one component of scientific expertise for policy making. The governance of the complex, global biosphere should be based on relatively primitive models, because such models can identify the most significant causal effects and major trends. Whether this approximate information is sufficient for the establishment of the limits to guide development, it is possible to judge only on the basis of a combination of scientific, social and pragmatic intelligence, which is fundamentally important in modeling such complex systems. This is why Moiseev did not limit his interest to mathematical modeling, but sought to transform the very conceptual and institutional contexts in which modeling was used: his theoretical ambition was to bridge the socalled "cultural lag" between advanced scientific and technological knowledge and societal and political values. ${ }^{83}$

This debate on the quality and use of models and data pointed to the fact that the post-cybernetic governance of the global biosphere required the repositioning of the institution of scientific expertise in relation to the government: for Moiseev, Soviet global modelers were not mere advisers (providers of feedback), but creators of the entire milieu for decision making. Furthermore, this Soviet vision of governance through milieu adds an important focus to the Foucauldian studies of negative, liberal governance, where governance through milieu is generally associated with the regulation of subjects considered unable to govern themselves. This approach enabled top-down government-at-a-distance without relying on the mechanism of self-regulation, as the capacity to self-regulate has been seen as absent in such subjects of governance as the working class, criminals or indigenous peoples. As Tony Bennett put it, "It is particularly in relation to populations that are excluded from the forms of self-action identified with liberal forms of subjectivity that the logic of government via milieus comes into play." 84

\footnotetext{
81 Moiseev, Aleksandrov and Tarko, Chelovek i biosfera, 34.

82 O'Riordan and Rayner, "Risk Management," 91.

83 Daniel Deudney and Elizabeth Mendenhall, "New Earths: Assessing Planetary Geographic Constructs," in Rens van Munster and Casper Sylvester, eds., The Politics of Globality since 1945: Assembling the Planet (London, 2016), 20-43, at 25-7.

84 Bennett, Making Culture, 37.
} 
In Moiseev's model of the negative government of the Earth system through the milieu of computer simulation the subjects who display a lack of what was deemed to be adequate self-regulation are Soviet government officials. By applying policy sciences to the global biosphere, Moiseev sought to alleviate the risk of environmental authoritarianism. In his vision of the noosphere, a scientifically governed Earth system, control does not flow top-down from the central government, but bottom-up, from internal, autonomous discussion among experts to the government decision makers. This can be understood as an attempt at liberalization without full democratization: Moiseev's model of government as guidance does not consider wider public engagement, but is restricted to securing a form of interaction between scientists and policy makers.

Nevertheless, it can be argued that the post-cybernetic governance through milieu can be important in those cases where strongly polarized political ideologies are at play and where political and administrative hierarchies are very strong. For example, mathematical language and computer modeling could enjoy a unique epistemological autonomy in the Soviet context of political censorship. Whereas Soviet literary and policy discourses were tightly controlled to communicate positive images of the Soviet future and technoscientific progress, paying explicit dues to the primacy of the Party in decision making, the modeling of the global Earth system represented innovative and critical thought beyond official planning. The intellectual mission of global modeling was to enhance awareness of the limits to human knowledge and control, socializing policy makers to accept uncertainty as an inevitable condition. Here Earth system modeling formed a socio-technical milieu where scientists could not be separated from the results crunched out by the computer: the interpretation of modeling results was not accessible to a nonspecialist; furthermore, tacit knowledge of how a particular mainframe computer worked was necessary to understand and evaluate the results. As global modelers held the monopoly of the production and interpretation of data about the past, current and future state of the global biosphere, they broke down the centralist structure of Party decision making. Furthermore, global modeling was expected to change the conceptual apparatus of what it means to govern by habituating policy makers into working without the notion of purposive control of individuals and societies, at least at the global level.

In this way, by developing a policy science for Earth system governance, Moiseev effectively contributed a building block for a new governmental milieu in the late Soviet Union. The political effect of this theory was "a new set of natural and social givens," where natural givens were the planetary boundaries, established with the help of computer-based modeling of global geophysical processes. The planetary boundaries as natural givens were only made possible by the invention of new social givens, transnational scientific networks that cut across the Iron Curtain and that were crucially important for the production 
and exchange of data describing the Earth system. Moiseev's extension of policy science to the global biosphere was not only an original intellectual experiment, but also an effort to intellectually transform existing Soviet policy practices, both institutionally and socially in the 1970 - -1980 s. $^{85}$

\section{CONCLUSION}

Just like the pioneers of cybernetics in the 1940s, many Earth system scientists created their own theories of sociopolitical governance as they were searching for new models of engagement with policy making. As Brian Wynne has repeatedly argued, climate science emerged not so much as a truth machine, but as realitybased social and policy heuristics, "an organising basis for a broader coalition of motivations, meanings, and social, ethical and political concerns." 86 The most recent debates among Earth system scientists themselves reveal a continued search for new governmental epistemologies and practices that could bridge the intellectual and political gap between scientific expertise and government. ${ }^{87}$ It is in this context that this article proposed viewing the Soviet case of Earth system governance as an instructive lesson in the politics of ideas at the changing interface between science and global governance.

This article has outlined Moiseev's extension of Vernadskii's ideas about the biosphere and noosphere to global governance, which resulted in the articulation of a liberal, negative, bottom-up mode of government through milieu. While in the West Teilhard de Chardin's noosphere theory remained mainly a philosophical explanation of the relationship between mankind and the Earth ${ }^{88}$ in the Soviet Union Vernadskii's writing about the noosphere unexpectedly inspired innovative policy thinking. Its legacy is still felt in today's Russia: through Moiseev's publications in the 1980s-1990s the noosphere spread as a model of a new, global governmental imagination, inspiring a diverse range

85 Egle Rindzevičiūtè, "Toward a Joint Future beyond the Iron Curtain: East-West Politics of Global Modelling," in Andersson and Rindzevičiūte, The Struggle for the Long Term, $115-43$.

86 Brian Wynne, "Strange Weather, Again: Climate Science as Political Art," Theory, Culture and Society 27/2-3 (2013), 289-305, at 295.

87 Ingrid Visseren-Hamakers, "Integrative Environmental Governance: Enhancing Governance in the Era of Synergies," Current Opinion in Environmental Sustainability 14 (2015), 136-43; Hans Joachim Schellnhuber and Volker Wenzel, eds., Earth System Analysis: Integrating Science for Sustainability (Berlin, 2013).

88 Pierre Teilhard de Chardin, The Phenomenon of Man (New York, 1959); Kenneth Boulding, Ecodynamics: A New Theory of Societal Evolution (London, 1978). 
of applications ${ }^{89}$ Intellectually, the post-cybernetic notion of control as guidance undermined several components of the very institutional identity of the Soviet system: centralized administration and branch-specific goal setting, the belief in linear control and, ultimately, the utopia of a bright, predictable future. This argumentation was made possible by the legitimacy that Soviet global modelers enjoyed, having contributed to the nuclear winter forecast; but it was also related to the political agenda of Gorbachev's perestroika. Most importantly, it was the global dimension of the complex Earth system which served as a proxy for articulation of these innovative ideas. For Moiseev, to govern in the age of the noosphere was to create a globally integrated governmentality, based on new institutions, but also on new intellectual models of control, able to make sense of complexity, remaining reflexive over the contingent coevolution of mankind and planet Earth.

In this respect, Moiseev's theory of governance through guidance entailed an epistemological revolution in the context of Soviet modernization, where scientific expertise was traditionally allocated the role of loyal service to political leaders. Governmental use of milieu to guide societal practices posited the importance of carefully orchestrated efforts of international scientists. In the Soviet Union, one of the first such milieus was the Gaia modeling system designed at the Computer Center in Moscow, which was used to simulate the environmental effects of nuclear war; acidification of water, soil and forests; and the impact of carbon dioxide on climate change. This epistemological infrastructure was mobilized by scientists to lobby for different policies, ranging from nuclear disarmament to reduction of pollution and of resource use. The global biosphere, materialized through computer systems, became a medium to govern the governor, the Party and industrial elites, an instrument of bottom-up activity.

89 The noosphere is often invoked in contemporary political discourses in Russia. One example is the theory of a Eurasian civilization, developed by the anthropologist Lev Gumilev (1912-92), that incorporated some mystical aspects of Vernadskii's noosphere theory. From the 1990s Gumilev's Eurasianism inspired a new era of Russian geopolitical thinking, according to which Russia is the hearth of a spiritual civilization, different from the rationalist West and therefore destined to become a world leader. In the 1990 os Moiseev too became attracted to Eurasianist ideas, writing about the North Eurasia continent as a geopolitical future of Russia. Furthermore, a peculiar version of Vernadskii's noosphere theory recently attracted international attention when it transpired that Vladimir Putin's newly appointed chief of staff, Anton Vaino, published several fairly senseless articles on government of the global noosphere, claiming to have developed a global predictive control machine, the nooscope. Anton Vaino, "Kapitalizatsiia budushchego" (Capitalization of the Future), Voprosy ekonomiki $i$ prava (Issues of Economics and Law) 4 (2012), 42-57. 
Many of the conceptual principles enshrined in Moiseev's framework of governance through guidance of the 1980 os remain relevant in the second decade of the third millennium, as world climate scientists continue trying to get to grips with issues of a similar character. The idea of prohibitive regulation found its implementation in the setting of "planetary boundaries," first approved by the international climate change scientists' collective in $2009.9^{\circ}$ The search for the "institutes of agreement" is continued, most visibly in the team led by Frank Bierman, seeking to develop a viable model of international environmental governance. The epistemological project of inquiring into the organizational forms of the coevolution of the social, living and nonliving matter is pursued in the STS field. While different conceptual approaches to the governance of complexity are tested by resilience scholars, it should not be forgotten that much of the vocabulary of resilience theory is derived from Cold War policy sciences. This is particularly important, because the bridging of Earth system sciences, the policy sciences and actual governmental practice remains a great challenge. Taken seriously, Moiseev's point that the cybernetic notion of purposive governance is fundamentally unsuitable for large-scale and long-term aspects of Earth system governance could open up new avenues for reconceptualizing government and control at the pragmatic level.

The last, but not least, important lesson that can be learned from the Soviet experience is that the history of the policy sciences can reveal the points where intellectual frameworks and social networks emerge and get disrupted. In the Soviet context of centralized planning and ideological control, Earth system policy science had an unexpected liberalizing effect. This is worth reflecting on. Instead of demonizing the policy sciences as tools of authoritarian technocrats and neoliberals, scholars should reengage in dialogue with policy science about the knowability and governability of the increasingly complex planetary system, perhaps even keeping the concept of the noosphere as a critical lens. One way of engaging would be an explicit discussion of the implications that the computer-based modeling of the Earth system can have as a milieu for liberal governmentality. This computer-mediated milieu might contribute as a governmental tool, recasting our understanding of uncertainty and indeterminacy not as failures of scientific expertise and control, but as necessary components of politics and governance, components that manifest the strength, not the weakness, of scientific understanding. ${ }^{91}$ The story of Moiseev shows that this task is even more important in nondemocratic regimes, for it could be a stepping stone for a more liberal governmental imagination.

90 Johan Rockstrom et al., "Planetary Boundaries: Exploring the Safe Operating Space for Humanity," Ecology and Society 14/2 (2009), 32; Steffen et al., "Planetary Boundaries."

91 Helga Nowotny, The Cunning of Uncertainty (Oxford, 2015). 